\title{
British Cardiovascular Society Young Investigator Award 2019
}

doi:10.1136/heartjnl-2019-315726

The four finalists for the 2019 British Cardiovascular Society (BCS) Young Investigator Award (YIA) were selected from a competitive pool of young researchers. At the BCS meeting in Manchester last June, each finalist gave a 10 min oral presentation, followed by questions from a panel of independent judges. All finalists were guests of the BCS at the Society's Annual Dinner, and first prize was awarded to Donna Page and presented by Dr Simon Ray, BCS President.

The details of the four YIA finalists and their academic training and interests can be seen below. We look forward to seeing new investigators and ideas at next year's meeting and encourage all those training in cardiovascular research to submit their best research to this competition.

\section{WINNER}

\section{Dr Donna J Page}

Identification of the major genetic contributors to tetralogy of Fallot

Dr Donna J Page is a Lecturer in Healthcare Science at Manchester Metropolitan University and an honorary Postdoctoral Research Associate at the University of Manchester(figure 1). She completed her $\mathrm{PhD}$ at the University of Manchester in the area of Cardiovascular Development with Dr Shane Herbert. Specifically, her work focused on the molecular control of blood vessel development using the zebrafish embryo model. Donna continued her postdoctoral studies at the University of Manchester in the area of Cardiovascular Genetics with Professor Bernard Keavney. The focus of her research is the genetics of congenital heart disease (CHD), the most common birth abnormality worldwide.

Dr Page's current research aims to delineate the causes of non-syndromic

\footnotetext{
Division of Cardiovascular Sciences, University of Manchester, Manchester, UK

${ }^{2}$ Department of Life Sciences, Manchester Metropolitan University, Manchester, UK

${ }^{3}$ Division of Cardiovascular Medicine, University of Oxford, Oxford, UK
}

Correspondence to Dr Donna Joanne Page, Manchester Metropolitan University, Manchester M1 5GD, UK; d.page@mmu.ac.uk

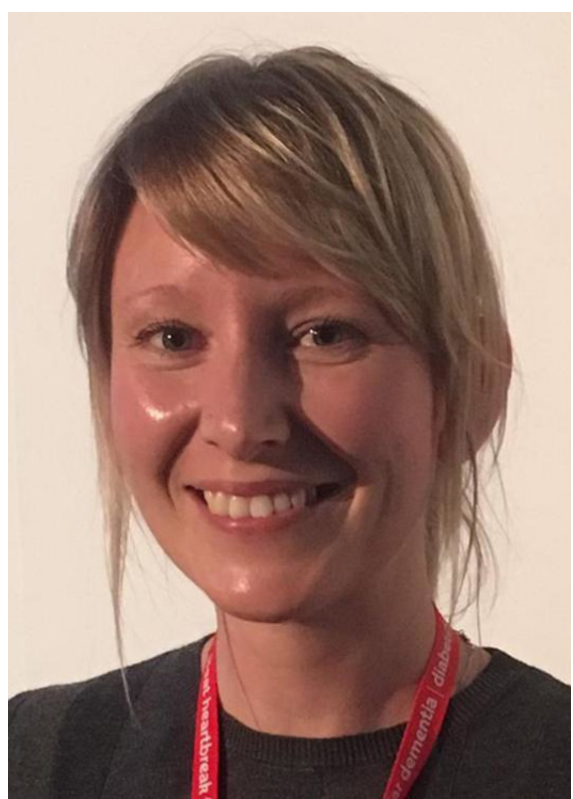

Figure 1 Dr Donna J Page

tetralogy of Fallot (TOF), the most common, cyanotic CHD subtype. Her recent work with the Keavney group led to the identification of two genes, NOTCH1 and FLT4, as the major genetic contributors to non-syndromic TOF. For her contribution to this work, Donna

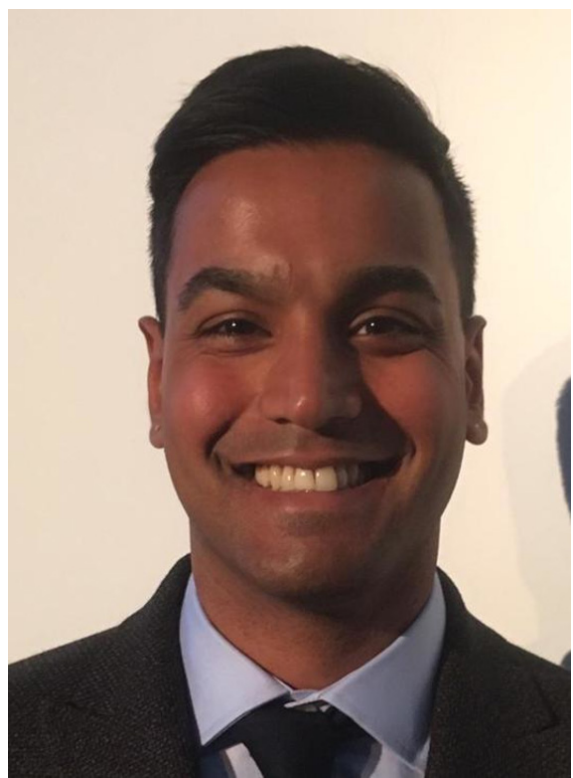

Figure 2 Dr Naveed Akbar was awarded the British Cardiovascular Society Young Investigator of the Year (2019). Donna continues to work closely with the Keavney group and her current focus is on understanding the functional impact of patient mutations in a number of novel TOF candidate genes and their contribution to the development of CHD.

\section{RUNNERS-UP}

\section{Dr Naveed Akbar}

Endothelial cell-derived extracellular vesicles mediate neutrophil deployment from the spleen following acute myocardial infarction Dr Naveed Akbar is a senior postdoctoral scientist and Fulford Junior Research Fellow (Somerville College) in the Division of Cardiovascular Medicine at the Oxford University (figure 2). Dr Akbar obtained a BSc (hons) in Human Biology before completing an MSc by research in Biomedical Sciences, where he developed an interest in vascular biology and undertook interdisciplinary training to synthesise and fabricate nanoparticles for vascular targeting. Dr Akbar went on to obtain his PhD in Medicine and Therapeutics at the University of Dundee, Scotland, where he investigated the role of innate

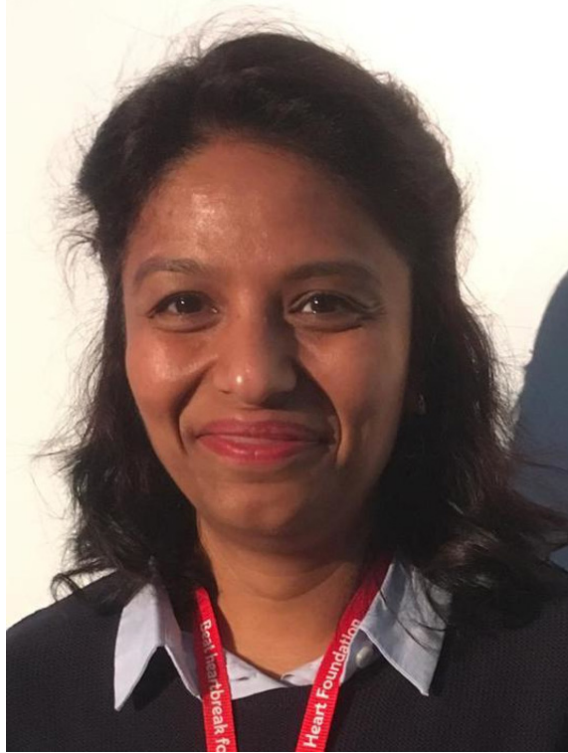

Figure 3 Dr Sonali Munshaw 
immune signalling in vascular inflammation using in vivo imaging.

Dr Akbar's current research investigates the role of extracellular vesicles in inflammation. Extracellular vesicles are small membrane enclosed particles that carry protein and genetic material. They can be produced, released and taken up by cells of the same origin or cells of different origin. Dr Akbar has shown that the number of extracellular vesicles rises in peripheral blood following acute myocardial infarction through enrichment of endothelial cell derived extracellular vesicles that can alter the cellular status of immune cells to mediate cell movement. Extracellular vesicles may provide diagnostic potential to better stratify patients for treatment following ischaemic injury and as tools for therapeutic targeting.

\section{Dr Sonali Munshaw}

Thymosin $\beta 4-$ a novel regulator of low density lipoprotein receptor related protein 1 (LRP1) in vascular disease

Dr Munshaw obtained an MSc in Biochemistry at the University of Madras, India, ranking second (figure 3). She joined the Experimental Radiation Therapeutic Group at the University of Oxford to study radiopharmaceutical treatment of Breast Cancer and subsequently joined Nicola Smarts' Group where she had the opportunity to explore the fields of Cardiac Regeneration and Vascular Protection. Dr Munshaw's increasing interest in the molecular mechanisms of cardiovascular disease motivated her to undertake a $\mathrm{PhD}$ in this field. She was awarded a prestigious MRC studentship and has presented work within the UK and abroad and has won awards including runner up in the BCS Young Investigator Award 2019.

Dr Munshaw is currently exploring the therapeutic potential of thymosin $\beta 4$ in aortic diseases and its role in regulating the extracellular matrix to protect the vasculature. We know that injury-induced growth factors stimulate a phenotypic switching of vascular smooth muscle cells and chronic de-differentiation. This leads to vascular thickening and stiffness, exacerbates inflammation and promotes

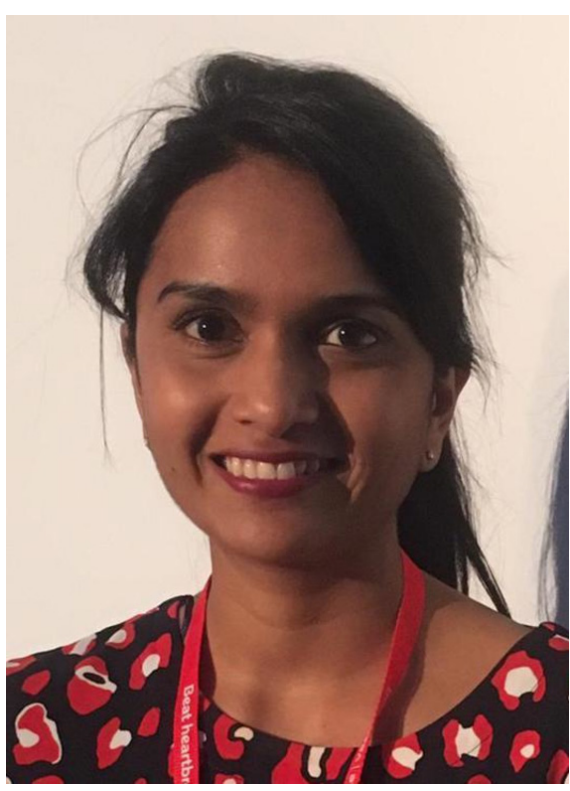

Figure 4 Dr Betty Raman

atherosclerotic lesion development and susceptibility to abdominal aortic aneurysm. Studies on vascular development in the embryo have provided novel insights into mechanisms that are important for maintenance of vessel stability throughout adult life. We have characterised a key regulatory pathway for maintaining vascular health which may enable us to identify novel therapeutic targets for modulation of vascular stability and disease progression.

\section{Dr Betty Raman}

Stress myocardial oxygenation and not perfusion reserve determines arrhythmic risk in hypertrophic cardiomyopathy: insights from a novel oxygen-sensitive CMR approach

After specialising in internal medicine and cardiology in Australia (2015), Dr Betty Raman undertook her doctoral studies at the University of Oxford investigating the role of multiparametric cardiac MRI (CMR) in hypertrophic cardiomyopathy (HCM)(figure 4). Dr Raman's work has received considerable recognition both nationally and internationally, having presented as a young investigator finalist in five meetings. Dr Raman has also been awarded many competitive scholarships including the National Heart Foundation of Australia
Scholarship, Cardiac Society of Australia and New Zealand Research Scholarship and NIHR Oxford Biomedical Research Centre Doctoral Fellowship. She has over 50 published conference abstracts and original articles (>15 publications) in peer-reviewed journals.

Dr Raman's work has focussed on trying to improve risk stratification in patients with HCM, the number one cause of sudden cardiac death in the young. Dr Raman and her colleagues have discovered a way to provide a more precise assessment of myocardial oxygenation using a technique called blood oxygen level dependent CMR. Using this approach, she showed that it is not only possible to detect subclinical changes in oxygen sensitive signal within the heart but also visualise this on CMR. She further demonstrated that patients with HCM with impaired stress oxygenation were at a threefold increased risk of life-threatening arrhythmias.

Funding The authors have not declared a specific grant for this research from any funding agency in the public, commercial or not-for-profit sectors.

Competing interests None declared.

Patient consent for publication Not required.

Provenance and peer review Commissioned; internally peer reviewed.

\section{(2) OPEN ACCESS}

Open access This is an open access article distributed in accordance with the Creative Commons Attribution Non Commercial (CC BY-NC 4.0) license, which permits others to distribute, remix, adapt, build upon this work non-commercially, and license their derivative works on different terms, provided the original work is properly cited, appropriate credit is given, any changes made indicated, and the use is non-commercial. See: http:// creativecommons.org/licenses/by-nc/4.0/.

(C) Author(s) (or their employer(s)) 2019. Re-use permitted under CC BY-NC. No commercial re-use. See rights and permissions. Published by BMJ.

$$
\text { D Check for updates }
$$

To cite Page DJ, Akbar N, Munshaw S, et al. Heart 2019;105:1841-1842.

Published Online First 21 September 2019

Heart 2019;105:1841-1842.

doi:10.1136/heartjnl-2019-315726

\section{ORCID iD}

Donna Joanne Page http://orcid.org/0000-0002-65605997 